\title{
KREDIT MACET DAN CARA MENGHADAPINYA
}

\author{
BAD CREDIT AND ITS SOLUTION
}

\author{
TRI ARTANTO \\ Program Studi Imu Hukum, Fakultas Hukum \\ Universitas Riau Kepulauan Batam, Indonesia \\ triartanto74@gmail.com
}

\begin{abstract}
Abstrak
Perekonomian Batam yang semakin memburuk pada masa ini, dimana banyak perusahaan yang tutup atau memindahkan usahanya ke negara lain yang dianggap memiliki regulasi dan kemudahan berusaha yang lebih baik dari Indonesia. Akibatnya angka pengangguran semakin bertambah saja, dimana banyak warga Batam yang semulanya bekerja dan kini menjadi pengangguran yang diakibatkan pemutusan hubungan kerja.Padahal sebelumnya mereka mempunyai kewajiban berupa kredit, yang dilakukan berupa pinjaman untuk memenuhi kebutuhan primer maupun sekunder.Kebutuhan primer dan sekunder itu berupa, peminjaman kredit perumahan dan kendaraan ataupun lainnya. Pinjaman kredit ini dilakukan kepada pihak Bank sebagai debitur, baik pinjaman ke Bank Umum maupun ke Bank Perkereditan Rakyat (BPR) ataupun lembaga Non Bank seperti lissing. Banyak masyarakat tidak memahami resiko dan dampak hukum yang tibul akibat kredit bermasalah sehingga banyak yang menghindar dari penagih hutang yang nantinya menimbulkan dampak yang lebih buruk. Metodologi yang digunakan dalam penulisan jurnal ini adalah metodelogi yuridis empiris. Adapun analisis data yang digunakan dalam penelitian ini dilakukan dengan menggunakan metode kualitatif yaitu dengan cara menganalisis data tanpa menggunakan perhitungan angka tetapi dengan menggunakan sumber informasi yang relevan untuk melengkapi data yang penulis lakukan. Perkreditan yang dilakukan oleh perbankan merupakan salah satu usaha penting bagi bank dalam mendapatkan keuntungan atau laba.Akan tetapi perlu dilakukan dengan prinsip kehati-hatian karena berbagai masalah atas penyaluran kredit bisa saja timbul dan yang harus dihadapi oleh perbankan tersebut. Hal ini akibatnya akan menimbulkan adanya kredit macet atau bermasalah yang biasa disebut Non Performance Loan (NPL) dengan jumlah yang cukup signifikan di sejumlah bank tersebut. Selain itu permasalahan Wanprestasi atau ingkar janji sering ditemui didalam pelaksanaannya baik berupa hak tanggungan maupun fidusia. Dalam penyelesaian kredit bermasalah tidak serta merta dengan melakukan sita jaminan atau ada jalur non litigasi dengan cara win-win solotion. Di harapkan masyarakat dapat megerti sehingga tiduk perlu menghindari Bank apa bila menunggak dan masyarakat lebih kooperatif dalam menyelesaikan kredit bermasalah. Ada banyak cara untuk menyelesaikan kredit bermasalah. Adanya kredit bermasalah (Non Performing Loan) akan menyebabkan menurunnya pendapatan bank, selanjutnya memungkinkan terjadinya penurunan laba.
\end{abstract}

Kata Kunci : Kredit Macet

\section{ABSTRACT}

Batam's economy is getting worse at this time, where many companies shutdown or move their business to other countries which are considered to have better in impelementing regulation compare than Indonesia. As a result, the unemployment rate is increasing only, where many Batam residents who initially worked and now become unemployed due to termination of employment. Whereas previously they have obligations in the form of credit, 
which is done in the form of loans to meet the needs of primary and secondary. Primary and secondary needs that form, mortgage loans and vehicles or other. This loan is made to the Bank as a debtor, either to the Bank or Public Bank Rakker (BPR) or Non Bank institution such as lissing. Many people do not understand the risks and legal impacts caused by non-performing loans so many are avoiding debt collectors that will have a worse impact. . The methodology used in the writing of this journal is the empirical juridical methodology. The data analysis used in this study was conducted by using qualitative methods that is by analyzing data without using numerical calculations but by using relevant sources of information to complement the data the author did. Credit performed by banking is one of important business for bank in getting profit. However, it needs to be done with the principle of prudence because of various problems on the channeling of credit may arise and which must be faced by the banking. This consequently will result in a bad credit or problem known as Non Performance Loan (NPL) with a significant amount in a number of these banks. In addition, the problem of paying their debt or broken promise is often encountered in the implementation either in the form of mortgage and fiduciary rights. In the settlement of non-performing loans does not necessarily with confiscation or nonlitigation path by win-win solotion. It is expected that the public can understand that they need to avoid what Banks are in arrears and the community is more cooperative in settling non-performing loans. There are many ways to resolve problem loans. The existence of Non Performing Loan problem loans will cause the decline in bank earnings, further allowing the decline in profits.

Keyword: Bad Credit

\section{PENDAHULUAN}

Dengan kondisi perekonomian Batam yang semakin memburuk pada masa ini,dimanabanyak perusahaan yang tutup atau memindahkan usahanya kenegara lain yang dianggap memiliki regulasi dan kemudahan berusaha yang lebih baik dari Indonesia. Akibatnya angka pengangguran semakin bertambah saja, dimana banyak warga Batamyang semulanya bekerja dan kini menjadi pengangguran yang diakibatkan pemutusan hubungan kerja.Padahal sebelumnya mereka mempunyai kewajiban berupa kredit, yang dilakukan berupa pinjaman untuk memenuhi kebutuhan primer maupun sekunder.Kebutuhan primer dan sekunder itu berupa, peminjaman kredit perumahan dan kendaraan ataupun lainnya.

Pinjaman kredit ini dilakukan kepada pihak Bank sebagai kreditur yang memberikan piutang kepada debitur, baik pinjaman ke Bank Umum maupun ke Bank Perkereditan Rakyat (BPR)ataupun lembaga Non Bank seperti leasing.Piutang itu sendiri memiliki arti "Piutang adalah hak untuk menerima pembayaran" (Pasal 1 Ayat 3, Undang-Undang Republik Indonesia Nomor 42 Tahun 1999 ). Undang-Undang Republik Indonesia Nomor 4 Tahun 1996 Tentang Hak Tanggungan Atas Tanah Beserta Benda-Benda Yang Berkaitan Dengan Tanah, menjelaskan :

Pasal 1

2. Kreditor adalah pihak yang berpiutang dalam suatu hubungan utang-piutang tertentu.

3. Debitor adalah pihak yang berutang dalam suatu hubungan utang-piutang tertentu. 
Leasing atau sewa guna adalah setiap kegiatan pembiayaan perusahaan dalam bentuk penyediaan barang-barang modal untuk digunakan oleh suatu perusahaan dalam jangka waktu tertentu.Dengan melakukan leasing perusahaan dapat memperoleh barang modal dengan jalan sewa beli untuk dapat langsung digunakan berproduksi, yang dapat diangsur setiap bulan, triwulan atau enam bulan sekali kepada pihak lessor. Lembaga leasing merupakan suatu alternatif yang menarik bagi para pengusaha atau masyarakat yang membutuhkan kemudahan dan dana cepat untuk memiliki suatu barang atau benda serta seringkali kita temukan dalam kehidupan sehari-hari.Melalui leasing masyarakat ataupun perusahaan bisa memperoleh dana untuk membiayai pembelian barang-barang modal dengan jangka waktu pengembalian antara tiga tahun hingga lima tahun atau lebih. Pengertian leasing menurut surat Keputusan Bersama Menteri Keuangan dan Menteri Perdagangan dan Industri Republik Indonesia No. KEP- 122/MK/IV/2/1974, Nomor 32/M/SK/2/1974, dan Nomor 30/Kpb/I/1974 tanggal 7 Februari 1974 adalah:

"Setiap kegiatan pembiayaan perusahaan dalam bentuk penyediaan barang-barang modal untuk digunakan oleh suatu perusahaan untuk jangka waktu tertentu, berdasarkan pembayaran-pembayaran secara berkala disertai dengan hak pilih bagi perusahaan tersebut untuk membeli barang-barang modal yang bersangkutan atau memperpanjang jangka waktu leasing berdasarkan nilai sisa uang telah disepakati bersama”.

Banyak masyarakat tidak memahami resiko dan dampak hukum yang tibul akibat kredit bermasalah sehingga banyak yang menghindar dari penagih hutang yang nantinya menimbulkan dampak yang lebih buruk. Kebutuhan akan hidup layak dan terkadang kebutuhan yang sifatnya konsumtif yang dilakukan oleh masyarakat mengakibatkan aktivitas yang dijalankan masyarakat tersebut sebenarnya selalu berhubungan dengan bank. Selain itu apabila masyarakat yang telah menerima dana pencairan kredit pada suatu bank baik itu bank pemerintah maupun bank swasta. Maka pada suatu ketika ia tidak lagi mampu membayar angsuran kredit pada Bank tersebut, maka ia telah melakukan suatu wanprestasi atau ingkar janji. Sehingga pihak perbankan memvonis kredit tersebut masuk kepada kategori kredit macet dan cara penyelesaiaan yang ditempuh adalah dengan cara melalui Pengadilan, Panitia Urusan Piutang Negara (PUPN), dan ada yang melalui Badan Penyehatan Perbankan Nasional (BPPN).

\section{METODOLOGI}


Tulisan ini juga menggunakan metode-metode tertentu agar suatu penulisan dapat mengarah pada tujuan yang telah ditentukan. Dalam hal ini "metodologi pada hakekatnya memberikan pedoman tentang tata cara seorang ilmuwan mempelajari, menganalisa dan memahami lingkungan yang dihadapinya (Soekanto,1984). Penelitian didalam penulisan jurnal ini adalah penelitian hukum yuridis empiris dengan peraturan perundang-undangan, yaitu "penelitian hukum mengenai pemberlakuan atau implementasi ketentuan hukum normatif secara in action pada setiap peristiwa hukum tertentu yang terjadi dalam masyarakat. (Muhammad, 2014).

Data primer adalah data yang diperoleh secara langsung di lapangan yang dalam hal ini diperoleh melalui wawancara dan system Tanya jawab kepada masyarakat, selain itu sistem wawancara yang dipergunakan dalam penelitian ini adalahwawancara bebas terlebih dahulu dipersiapkan daftarpertanyaan sebagai pedoman. Bahan sekunder yaitu bahan hukum yang memberikan penjelasan mengenai bahan hukum primer, dan bahan hukum tertier yakni bahan yang memberikan petunjuk maupun penjelasan terhadap bahan hukum primer dan sekunder (Soekanto, 1994). Untuk mengumpulkan data dari sumber-sumber yang telah disebutkan di atas, digunakan teknik pengumpulan data berupa :

a. Studi Kepustakaan. Yaitu dengan mempelajari literatur-literatur, dokumendokumen,peraturan perundang-undangan dan pendapat para ahli yangberhubungan dengan pokok permasalahan dan akan dipergunakan sebagailandasan pemikiran yang bersifat teoretis.

b. Wawancara. Wawancara dilakukan untuk melengkapi informasi yang dibutuhkan berupa data primer teknik wawancara yang digunakan adalah wawancara semi terstruktur, yaitu wawancara yang tidak hanya terbatas pada pertanyaan yang telah disusun namun juga dikembangkan berdasarkan informasi yang disampaikan oleh pihak yang bersangkutan.

Adapun analisis data yang digunakan dalam penelitian ini dilakukan dengan menggunakan metode kualitatif yaitu dengan cara menganalisis data tanpa menggunakan perhitungan angka tetapi dengan menggunakan sumber informasi yang relevan untuk melengkapi data yang penulis lakukan.

\section{PEMBAHASAN}

\section{Pengertian Kredit Dengan Hak Tanggungan}


Untuk lebih jelasnya apa itu kredit, pengertian kredit adalah "suatu penyediaan uang atau tagihan yang dapat dipersamakan dengan itu, berdasarkan persetujuan atau kepsekatan pinjam-meminjam antara bank dengan pihak lain yang mewajibkan pihak peminjam untuk melunasi utangnya setelah jangka waktu tertentu dengan pemberian bunga (UU.No. 10 Tahun 1998, Pasal 1 ayat 11). Surat Keputusan Direksi Bank IndonesiaNomor 31/147/KEP/DIR tanggal 12 November 1998 tentang Kualitas AktivaProduktif, Pasal 1 ayat 3 yang berbunyi : Kredit adalah penyediaan uang atau tagihan yang dapat dipersamakandengan itu, berdasarkan persetujuan atau kesepakatan pinjam-meminjamantara Bank dengan pihak lain yang mewajibkan pihak peminjam untukmelunasi utangnya setelah jangka waktu tertentu dengan pemberian bunga,termasuk :

a. pembelian surat berharga nasabah yang dilengkapi dengan Note

Purchase Agreement (NPA);

b. pengambilalihan tagihan dalam rangka anjak piutang.

Pemberian platfon kredit biasanya didalam prakteknyadiawali dengan suatu kesepakatan yang dituangkan dalam suatu perjanjian kredit. Adapun yang menjadi dasar hukum dalam suatu perjanjian adalah perjanjian diantara pihak yaitu Pasal 1338 ayat (1) KUH Perdata menyatakan bahwa "semua perjanjian yang dibuat secara sah berlaku sebagai undang-undang bagi yang membuatnya”. Hukum kebiasaan di Indonesiapun bisa menjadi sumber hukum dan begitu pula terkadang kebiasaan perbankan juga dalam prakteknya dapat juga dijadikan suatu sumber hukum bagi perbankan tersebut dengan dijadikan suatu aturan yang yang dipatuhi, asalkan tidak bertentangan dengan norma-norma ataupun peraturan perundang-undangan yang berlaku.Demikian pula didalam bidang perkreditan, kebiasaan dan praktek perbankan dapat jugamenjadi suatu dasar hukumnya.

Perkreditan yang dilakukan oleh perbankan merupakan salah satu usaha penting bagi bank dalam mendapatkan keuntungan atau laba.Akan tetapi perlu dilakukan dengan prinsip kehati-hatian karena berbagai masalah atas penyaluran kredit bisa saja timbul dan yang harus dihadapi oleh perbankan tersebut. Hal ini akibatnya akan menimbulkan adanya kredit macet atau bermasalah yang biasa disebut Non Performance Loan (NPL) dengan jumlah yang cukup signifikan di sejumlah bank tersebut. Kredit bermasalah merupakan resiko yang acapkali kita temui dalam setiap pemberian kredit oleh bank kepada nasabahnya.Adapun resiko tersebut berupa keadaan di mana kredit tidak sesuai dengan perjanjian awal yang disepakati dan pengembaliankredit tidak tepat pada waktunya, ingkar janjiatau wanprestasi. 
Kredit bermasalah di perbankan itu dapat di sebabkan oleh beberapa faktor, misalnya adanya faktor kesengajaan dari pihak-pihak yang terlibat dalam proses kredit, kesalahan prosedur pemberian kredit atau disebabkan faktor lain seperti faktor mikro ekonomi seperti yang terjadi di Batam yang disebabkan oleh pemutusan hubungan kerja dan menimbulkan naikknya angka pengangguran. Pemberian kredit yang tertuang dalam suatu perjanjian tidak dapat dilepaskan dari prinsip kepercayaan, yang sering menjadi sumber permasalahan bagi kreditur terhadap kredit macet yang terjadi. Dalam pengiktan jaminan kredit baik bagi Bank atau lembaga pembiyaan ada 2 hal yang sering dilakukan:

\section{Akta Pemberian Hak Tanggungan}

APHT mengatur persyaratan dan ketentuan mengenai pemberian Hak Tanggungan dari debitor kepada kreditor sehubungan dengan hutang yang dijaminkan dengan Hak Tanggungan. Pemberian hak ini dimaksudkan untuk memberikan kedudukan yang diutamakan kepada kreditor yang bersangkutan (kreditor preferen) daripada kreditor-kreditor lain (kreditor konkuren) sesuai dengan yang dimaksud pasal 1ayat 1 Undang-undang No.4 Tahun 1996 tentang UUHT yang berbunyi :

"Hak Tanggungan, adalah hak jaminan yang dibebankan pada hak atas tanah sebagaimanadimaksud dalam Undang-Undang Nomor 5 Tahun 1960 tentang Peraturan Dasar Pokok-Pokok Agraria,berikut atau tidak berikut benda-benda lain yang merupakan satu kesatuan dengan tanah itu, untukpelunasan utang tertentu, yang memberikan kedudukan yang diutamakan kepada kreditor tertentuterhadap kreditor-kreditor lain".

Adapun Pemberian Hak Tanggungan adalah sebagai jaminan pelunasan hutang debitor kepada kreditor sehubungan dengan perjanjian pinjaman/kredit yang bersangkutan.

\section{Fidusia}

Pengertian Fidusia adalah pengalihan hak kepemilikan suatu benda atas dasar kepercayaan denganketentuan bahwa benda yang hak kepemilikannya dialihkan tersebut tetap dalampenguasaan pemilik benda. Selain itu apa yang dimaksud Jaminan Fidusia adalah hak jaminan atas benda bergerak baik yang berwujud maupun yangtidak berwujud dan benda tidak bergerak khususnya bangunan yang tidak dapat dibebanihak tanggungan yang tetap berada dalam penguasaan Pemberi Fidusia,sebagaiagunan bagi pelunasan utang tertentu, yang memberikan kedudukan yang diutamakankepada Penerima Fidusia terhadap kreditor lainnya. 
Pasal 1 ayat 6 dan 7 UU Undang-Undang Republik IndonesiaNomor 42 Tahun 1999 Tentang Jaminan Fidusia :

6. Penerima Fidusia adalah orang perseorangan atau korporasi yang mempunyai piutang yangpembayarannya dijamin dengan Jaminan Fidusia.

7. Utang adalah kewajiban yang dinyatakan atau dapat dinyatakan dalam jumlah uang baikdalam mata uang Indonesia atau mata uang lainnya, baik secara langsung maupunkontinjen.

Sebagai gambaran dan contoh, seseorang atau debitur melakukan kredit kendaraan bermotor dan membeli kendaraan bermotor tersebut kepada pihak dealer atau kreditur.Selagi debitur belum melunasi kredit kendaraan bermotor tersebut kepada dealer maka motor tersebut masih milik pemberi kredit atau dealer, yang mana kendaraan bermotor tersebut adalah milik pemberi kredit dan hak miliknya dialihkan kepada pembeli kendaraan bermotor tersebut.

\section{Kredit macet dan penarikan Fidusia}

Kredit Macet berdasarkan Surat Keputusan Direksi Bank Indonesia Nomor 31/147/KEP/DIR tanggal 12 November 1998 memberikan penggolongan mengenai kualitas kredit yang diberikan oleh bank, terdiri dari :

1. Kredit lancar

2. Kurang lancar

3. Diragukan

4. Macet

Kredit macet adalah kredit yang mengalami kesulitan pelunasan hutang akibat adanya faktor-faktor atau unsur kesengajaan atau karena kondisi di luar kemampuan debitur.Lebih lanjut pengertian kredit macet adalah suatu keadaan di mana seorang nasabah tidak mampu membayar lunas kredit bank tepat pada waktunya. Adapun beberapa jenis pelunasan atau kualitas kredit adalah :

1. Nasabah sama sekali tidak dapat membayar angsuran kredit beserta bunganya (kredit macet).

2. Nasabah membayar sebagian angsuran kredit beserta bunganya (kurang lancer)

3. Nasabah membayar lunas kredit beserta bunganya setelah jangka waktu yang diperjanjikan berakhir (kredit lancar).

Penarikan fidusia diatur pada :

1. Peraturan Kapolri nomor 8 tahun 2011 tentang pengamanan eksekusi jaminan fidusia 
2. PMK No. 130.10/2012 tentang pendaftaran jaminan fidusia

Salah satu bunyi dari Peraturan Kapolri nomor 8 tahun 2011 tentang pengamanan eksekusi jaminan fidusia. Bahwa eksekusi Jaminan Fidusia mempunyai kekuatan hukum mengikat yang sama dengan putusan pengadilan yang telah berkekuatan hukum tetap, sehingga memerlukan pengamanan dari Kepolisian Negara Republik Indonesia.

Tujuan yang meliputi terselenggaranya pelaksanaan eksekusi jaminan Fidusia secara aman, tertib, lancar, dan dapat dipertanggung jawabkan.terlindunginya keselamatan dan keamanan Penerima Jaminan Fidusia, Pemberi Jaminan Fidusia, dan/atau masyarakat dari perbuatan yang dapat menimbulkan kerugian harta benda dan/atau keselamatan jiwa.

Peraturan Kapolri nomor 8 tahun 2011 tentang pengamanan eksekusi jaminan fidusia, mewajibkan kreditur untuk mendaftarkan jaminan fidusia pada kantor fidusia, yang berbunyi :

\section{Pasal 5}

(1) Objek pengamanan jaminan fidusia sebagaimana dimaksud dalam Pasal 4 dilaksanakan terhadap benda jaminan yang telah didaftarkan di kantor pendaftaran fidusia.

(2) Kantor pendaftaran fidusia sebagaimana dimaksud pada ayat (1) berada pada lingkup tugas Kementerian Hukum dan HAM.

Peraturan Menteri Keuangan (PMK) Nomor 130/PMK.010/2012, tentang Pendaftaran Jaminan Fidusia bagi perusahaan pembiayan yang melakukn pembiayaan konsumen untuk kendaraan bermotor dengan pembebanan jaminan fidusia.Perusahaan pembiayaan wajib mendaftarkan jaminan fidusia dimaksud, guna memberikan kepastian hukum bagi perusahaan pembiayaan dan konsumen.Sehubungan dengan penyerahan hak milik atas kendaraan bermotor dari konsumen secara kepercayaan (fidusia) kepada perusahaan pembiayaan.

Pasal 1 ayat 1 PMK ini mengatur "Perusahaan Pembiayaan yang melakukan pembiayaan konsumen untuk kendaraan bermotor dengan pembebanan jaminan fidusia wajib mendaftarkan jaminan fidusia dimaksud pada Kantor Pendaftaran Fidusia, sesuai undangundang yang mengatur mengenai jaminan fidusia".

Peraturan Menteri Keuangan mewajibkan pendaftaran jaminan fidusia berlaku pula bagi perusahaan pembiayaan yang melakukan pembiayaan konsumen kendaraan bermotor 
berdasarkan prinsip syariah, atau pembiayaan konsumen kendaraan bermotor yang pembiayaannya berasal dari pembiayaan penerusan (channeling) atau pembiayaan bersama (joint financing).

Pasal 2 PMK 130 tahun 2012 ini mengatur "Perusahaan pembiayaan wajib mendaftarkan jaminan fidusia pada kantor pendaftaran fidusia paling lama 30 hari kalender terhitung sejak tanggal perjanjian pembiayaan konsumen”.

Selain itu, perusahaan multifinance dilarang melakukan penarikan benda jaminan fidusia berupa kendaraan bermotor, apabila kantor pendaftaran fidusia belum menerbitkan sertifikat jaminan fidusia dan menyerahkannya kepada perusahaan multifinance. Penarikan benda jaminan fidusia berupa kendaraan bermotor oleh perusahaan multifinance wajib memenuhi ketentuan dan persyaratan sebagaimana diatur dalam undang-undang mengenai jaminan fidusia dan telah disepakati oleh para pihak dalam perjanjian pembiayaan konsumen kendaraan bermotor.

\section{Penyelesaian Kredit Macet}

\section{Penyelesaian kredit bermasalah melalui jalur non litigasi}

Penyelesaian melalui jalur ini dilakukan melalui perundingan kembali antara Kreditor dan debitur, dengan memperingan syarat-syarat dalam perjanjian kredit.Jadi dalam tahap penyelamatan kredit ini belum memanfaatkan lembaga hukum karena debitur masih kooperatif dan dari prospek usahanya masih feasible. Penanganan kredit perbankan yang bermasalah menurut ketentuan Surat Edaran Bank Indonesia No. 23/12/ BPP tanggal 28 Februari 1991 dalam usaha mengatasi kredit macet, pihak bank dapat melakukan beberapa tindakan penyelamatan sebagai berikut :

\section{Rescheduling/ penjadwalan kembali}

Rescheduling merupakan upaya pertama dari pihak bank untuk menyelamatkan kredit yang diberikan kepada debitor.Ini dilakukan jika ternyata bila pihak debitur atas dasar hasil penelitian dan perhitungan yang dilakukan pihak bank yaitu account officer bank tidak mampu untuk memenuhi kewajiban dalam hal pembayaran kembali angsuran pokok maupun bunga kredit yang telah disepakati. Rescheduling adalah penjadwalan kembali sebagian atau seluruh kewajiban debitor.Hal tersebut disesuaikan dengan proyeksi arus kas yang bersumber 
dari kemampuan usaha debitur yang sedang mengalami kesulitan. Penjadwalan tersebut antara lain :

1) Memperpanjang jangka waktu kredit

2) Memperpanjang jangka waktu angsuran, misalnya semula angsuran ditetapkan setiap 3 bulan kemudian menjadi 6 bulan

3) Menurunkan jumlah untuk setiap angsuran yang mengakibatkan perpanjangan jangka kredit

\section{Reconditioning}

Persyaratan kembali (reconditioning), yaitu perubahan sebagian atau seluruh syaratsyarat kredit yang tidak terbatas pada perubahan jadwal pembayaran, jangka waktu dan atau persyaratan lainnya sepanjang tidak menyangkut perubahan maksimun saldo kredit yang telah disepakati. Langkah-langkah upaya penyelamatan kredit secara reconditioning bertujuan untuk :

1) Menyempurnakan legal documentation

2) Menyesuaikan kemampuan membayar debitor dengan kondisi yang terjangkau oleh debitur berupa angsuran pokok, denda, bunga, penalti dan biaya-biaya lainnya.

3) Memperkuat posisi bank

\section{Recstructing.}

Reksrtukturisasi adalah suatu usaha penyelamatan kredit yang terpaksa harus dilakukan bank dengan cara mengubah komposisi pembiayaan yang mendasari pemberian suatu kredit.Secara umum tujuan dilakukannya rekstrukturisasi kredit adalah meningkatkan kemampuan debitor dalam membayar pokok dan bunga jaminan.Dalam melakukan rekstrukturisasi kredit hal yang harus diperhatikan adalah prospek usaha dan itikad baik debitur. Restructing atau rekstrukturisasi menurut Surat Keputusan Direksi Bank Indonesia Nomor 31/150/KEP/DIR tanggal 12 November 1998 tentang Rekstrukturisasi kredit dalam Pasal 1 huruf c adalah "upaya yang dilakukan bank dalam kegiatan usaha perkreditan agar debitor dapat memenuhi kewajibannya. Rektrukturisasi kredit dapat dilakukan dengan caracara sebagai berikut :

1) Penurunan suku bunga kredit. Penurunan suku bunga kredit tidak dapat dikatakan sebagai rekstrukturisasi kredit apabila penurunan dimaksud bertujuann menyesuaikan dengan bunga pasar yang pada saat bersamaan juga mengalami 
penurunan. Kaitannya dengan Batas Maksimum Pemberian Kredit (selanjutnya disingkat menjadi BMPK), perpanjangan jangka waktu yang sebelumnya telah melampaui BMPK diberlakukan sebagai pelampauan BMPK yang wajib diselesaikan dalam jangka waktu 9 bulan sedangkan penyertaan modal sementara dalam rangka rektrukturisasi kredit dikecualikan dari perhitungan BMPK.

2) pengurangan tunggakan bunga kredit, kreditor dapat memberikan keringanan berupa mengurangi jumlah bunga yang tertunggak atau menghapus seluruh tunggakan bunga kredit. Debitor dibebaskan dari kewajiban membayar tunggakan bunga kredit sebagian atau seluruhnya.Langkah ini diambil agar debitor mempunyai kembali kemampuan melanjutkan kegiatan usahanya sehingga dapat digunakan membayar utang pokoknya.

3) Pengurangan tunggakan pokok kredit. Kreditor dapat memberikan keringanan berupa mengurangi utang pokok yang tertunggak.Langkah ini merupakan reksstrukturisasi yang paling maksimal yang dapat diberikan oleh bank karena langkah ini biasanya diikuti dengan penghapusan bunga dan denda seluruhnya. Pengurangan tunggakan pokok ini merupakan pengorabanan yang tidak kembali dan merupakan kerugian bagi bank.

4) Perpanjangan waktu kredit. Perpanjangan waktu kredit merupakan bentuk rekstrukturisasi kredit yang bertujuan memperingan debitor untuk mengembalikan hutangnya.Diharapkan dengan perpanjangan waktu ini dapat memberikan kesempatan kepada debitor untuk melanjutkan usahanya sehingga pendapatan yang harusnya digunakan untuk membayar hutang digunakan untuk memperkuat usahanya.

5) Penambahan fasilitas kredit. Dalam hal ini rektrukturisasi kredit dilakukan dengan cara penambahan fasilitas kredit yang harus digunakan sesuai prosedur yang ketat dan terdapat agunan yang cukup. Dengan adanya penambahan fasilitas kredit dimana debitor diberikan kredit lagi sehingga utang menjadi besar nantinya diharapkan debitor dapat mempunyai kemampuan untuk menjalankan kembali usahanya dan pendapatan dari usahanya dapat digunakan untuk membayar utang lama dan utang baru.

6) Pengambilalihan asset debitor sesuai dengan ketentuan yang berlaku. Pengambilalihan asset debitor sesuai dengan ketentuan yang mengacu kepada 
Undang-Undang perbankan khususnya Pasal 12A yang mengatur kemungkinan Bank Umum dapat membeli sebagian atau seluruh anggunan baik melalui penjualan umum atau pelelangan ataupun diluar pelelangan berdasarkan penyerahan secara sukarela Namun kemudahan ini oleh undang-undang diadakan pembatasan yaitu :

1. Agunan yang dapat dibeli oleh bank adalah agunan dari kredit macet.

2. Agunan yang telah dibeli wajib dicairkan selambat-lambatnya dalam jangka waktu 1 tahun.

\section{Penyelesaian Kredit Bermasalah apabila macet secara Litigasi}

\section{Mengajukan gugatan ke Pengadilan Negeri.}

Kreditur atau bank dapat memberikan somasi atau peringatan kepada debitor agar ia memenuhi kewajiban, namun somasi secara yuridis tidak mempunyai akibat hukum yang memaksa pada debitor. Apabila somasi itu tidak ditanggapi oleh debitor, maka kreditor atau bank dapat melakukan gugatan ke Pengadilan Negeri. Kreditur pemegang jaminan kebendaan memiliki hak untuk mengeksekusi barang jaminan untuk dijual secara lelang guna pembayaran utang debitur jika debitur lalai melaksanakan kewajibannya berdasarkan perjanjian kredit atau biasa disebut dengan wanprestasi. Pemberian hak kepada kreditur untuk mengeksekusi jaminan kebendaan yang diberikan oleh debitur dapat dilihat padaKitab Undang-Undang Hukum Perdataserta beberapa peraturan perundang-undangan berikut ini:

1. Pasal 1155 KUH Perdata : Kreditur sebagai penerima benda gadai berhak untuk menjual barang gadai, setelah lewatnya jangka waktu yang ditentukan, atau setelah dilakukannya peringatan untuk pemenuhan perjanjian dalam hal tidak ada ketentuan jangka waktu yang pasti.

2. Pasal 15 ayat (3) jo. Pasal 29 Undang-Undang No. 42 Tahun 1999 tentang Jaminan Fidusia,yang memberikan hak kepada kreditur untuk mengeksekusi benda jaminan fidusia jika debitur cidera janji (wanprestasi).

3. Pasal 6 dan Pasal 20Undang-Undang No. 4 Tahun 1996 tentang Hak Tanggungan Atas Tanah Beserta Benda-Benda Yang Berkaitan Dengan Tanah: yang memberikan hak kepada kreditur untuk mengeksekusi benda jaminan fidusia jika debitur cidera janji.

Kemudian apabila terbukti hakim akan mengeluarkan keputusan Pengadilan yang tetap. Namun bila tergugat atau debitor tidak melaksanakan putusan pengadilan kreditor atau penggugat dapat mengajukan permohonan eksekusi dan melakukan sita eksekusi untuk 
selanjutnya melelang harta tergugat sehingga hasil lelangan dapat digunakan untuk melunasi hutang tergugat. Penjelasan tentang wanprestasi dapat dilihat pada Penjelasan Pasal $21 \mathrm{UU}$ Jaminan Fidusia, yaitu yang dimaksud dengan "cidera janji" (wanprestasi) adalah tidak memenuhi prestasi, baik yang berdasarkan perjanjian pokok, perjanjian Jaminan Fidusia, maupun perjanjian jaminan lainnya. Pada dasarnya jika terjadi wanprestasi atas perjanjian kredit dengan dengan Bank.Maka ketentuan pasal 20 ayat (1) UU Hak Tanggungan, Bank memiliki hak untuk menjual objek Hak Tanggungan dan mengambil pelunasan atas utang debitur dari hasil penjualan rumah tersebut. Pada penjelasan Pasal 20 ayat (1) UU Hak Tanggungan dikatakan bahwa dalam hal hasil penjualan itu lebih besar daripada utangnya, sisa hasil penjualan objek Hak Tanggunganmenjadi hak debitur dan apabila jika hasil penjualan objek Hak Tanggungan tersebut tidak cukup untuk melunasi utang tersebut, maka debitur masih mempunyai utang yang harus dilunasi kepada Bank. Atas dasar kekurangan pembayaran utang tersebut, Bank dapat melakukan gugatan wanprestasi.

\section{Eksekusi jaminan kredit}

Mekanisme eksekusi jaminan kredit bila jaminan diikat secara formal atau melalui bantuan notaris untuk membuatkan aktanya (grosse akta/ akta hipotek/ akta hak tanggungan) maka kreditor cukup mengajukan permohonan eksekusi kepada pengadilan yang berkompeten." Bila ternyata debitor tetap tidak melaukannya maka kreditor akan memohon sita eksekusi. Kemudian dengan sita eksekusi tersebut juru sita pengadilan melakukan sita jaminan yang biasanya disertai permohonan kreditor untuk pelelangan jaminan. Lalu, pengadilan berdsarkan permohonan lelang dari kreditor akan menghubungi kantor lelang untuk melaksanakan lelang atas jaminan tersebut. Setelah pelelangan dilakukan, kreditor bisa mengambil pinjaman dengan perhitungan yang sudah diketahui pengadilan dari harga jaminan yang terjual.

\section{Parate Eksekusi Hak tanggungan}

Pemegang hak tanggungan dapat memilih cara menjual lelang objek hak tanggungan berdasarkan kekuasaan sendiri (Pasal 6 jo. Pasal 11 ayat (2e) Undang-Undang Nomor 4 Tahun 1996), maka pemegang hak tanggungan sama sekali tidak perlu berhubungan dengan pengadilan. "Kreditor pemegang Hak Tanggungan cukup meminta bantuan Kantor Lelang Negara untuk menjual obyek hak tanggungan tersebut. Tatacara BPPN dalam menjalankan tugasnya adalah : 
1. Penerbitan Surat Paksa Penerbitan Surat Paksa diatur dalam pasal 56 ayat (1) Peraturan Pemerintah nomor 17 tahun 1999, yang memiliki kekuatan eksekutorial dan berkedudukan sama dengan putusan pengadilan yang telah mempunyai kekuatan hukum tetap. Penerbitan Surat Paksa ini dilakukan sepanjang debitor telah melalaikan kewajiban membayar atau kewajiban lainnya berdasarkan dokumen kredit, dokumen pemberian hak jaminan, pernyataan yang telah dibuat sebelumnya dan atau dokumen lainnya dan kepada debitor atau penanggung hutang telah terlebih dahulu diberi surat peringatan melalui surat tercatat untuk membayar atau dokumen lain yang nilainya sama seperti itu.

2. Penyitaan. Dalam jangka waktu 1 (satu) hari setelah diterimanya Surat Paksa, BPPN berwenang melakukan sita eksekusi atas seluruh kekayaan debitor termasuk yang berada di tangan pihak ketiga kecuali barang-barang yang masih dibutuhkan untuk kelangsungan hidupnya.Surat penyitaan harus memenuhi syarat Pasal 58 dan dilakukan oleh juru sita dibantu 2 (dua) orang saksi dan dituangkan dalam berita acara penyitaan. Berita acara penyitaan diserhkan pada kantor pertanahan

3. Pelelangan. Penjualan kekayaan miliik debitor yang telah disita dilakukan melalui pelelangan, pembagian hasil pelelangan diserahkan untuk melunasi pemenuhan pembayaran piutang negara terdahulu. Upaya hukum lainnya tidak dapat mencegah BPPN untuk mengambil pelunasan piutang negara termasuk upaya hukum uuntuk mencegah atau menunda pelaksanaan tindakan hukum lain. Wewenang BPPN juga adalah menerbitkan surat pencabutan sita apabila debitor telah melunasi hutangnya, selanjutnya kantor pendaftaran mencabut blookir dan mengangkat sita eksekusinya.

Sengketa kredit macet termasuk dalam kewenangan peradilan umum sehingga penyelesaian kredit macet adalah kewenangan Pengadilan Negeri.Adapun penyelesaian melalui Pengadilan Negeri dengan 2 (dua) cara:

1. Bank menggugat nasabah karena telah melakukan wanprestasi atas perjanjian kredit yang telah disepakati. Putusan tersebut dilaksanakan dengan sita eksekusi atas agunan yang diberikan untuk kepentingan pelunasan kredit.

2. Bank meminta penetapan sita eksekusi terhadap barang agunan debitur yang telah diikat secara sempurna. Barang agunan yang telah diikat dengan Hak Tanggungan oleh bank dan bank dapat langsung mengajukan permohonan penetapan sita 
eksekusi barang agunan untuk dapat memperoleh pelunasan piutangnya, tanpa perlu melalui proses gugatan di Pengadilan.

\section{KESIMPULAN}

Dalam penyelesaian kredit bermasalah tidak serta merta dengan melakukan sita jaminan atau ada jalur non litigasi dengan cara win-win solotion.Di harapkan masyarakat dapat megerti sehingga tiduk perlu menghindari Bank apa bila menunggak dan masyarakat lebih kooperatif dalam menyelesaikan kredit bermasalah.Ada banyak cara untuk menyelesaikan kredit bermasalah.

Adanya kredit bermasalah (Non Performing Loan) akan menyebabkan menurunnya pendapatan bank, selanjutnya memungkinkan terjadinya penurunan laba. Sarana hukum yang dapat dipergunakan untuk mempercepat penyelesaiaan masalah kredit macet perbankan melalui pelaksanaan pasal 1178 ayat (2) KUH Perdata Kreditur Pemegang Hak Tanggungan Pertama dapat diberi kuasa untuk menjual barang agunan dimuka umum untuk melunasi hutang pokok atau bunga yang tidak dibayar oleh debitur sebagaimana mestinya, dan dengan cara pemegang grosse akte dapat mengajukan permohonan kepada Ketua Pengadilan Negeri setempa

\section{REFERENSI}

Abdulkadir Muhammad, Hukum dan Penelitian Hukum, Citra Aditya Bakti, Bandung, 2014. Soerjono Soekanto, Pengantar Penelitian Hukum, Jakarta : UI Pres 1984.

UU no.10 tahun 1998 tentang perubahan atas UU no.7 tahun 1992 tentang perbankan Kitab Undang-undang Hukum Perdata

UU nomor 4 tahun 1996 tentang hak tanggungan atas tanah beserta benda-benda yang berkaitan dengan tanah

UU nomor 42 tahun1999 tentang jaminan fidusia

Peraturan kapolri nomor 8 tahun 2011 tentang pengamanan eksekusi jaminan fidusia PMK no 130/PMK.10/2012 tentang pendaftaran jaminan fidusia Surat keputusan di reksi bank indonesia nomor 31/147/KEP/DIR tanggal 12 november 1998 
Surat keputusan direkasi bank indinesia nomor 31/150/KEP/DIR tanggal 12 noveber 1998 tentang restrukturisasi kredit

Surat Keputusan Direksi Bank Indonesia Nomor 31/147/KEP/DIR tanggal 12 November 1998 tentang Kualitas Aktiva Produktif 